JOURNAL OF SECURITY AND SUSTAINABILITY ISSUES

ISSN 2029-7017 print/ISSN 2029-7025 online

2019 September Volume 9 Number 1

http://doi.org/10.9770/jssi.2019.9.1(9)

\title{
Scopus
}

\section{ORGANIZATIONAL CULTURE AS A COMPONENT OF PERSONNEL SECURITY OF THE ENTERPRISE}

\author{
Oksana Osetrova ${ }^{1}$, Olga Prykhodko ${ }^{2}$, Stanislav Glazunov ${ }^{3}$, Yuliia Borysova ${ }^{4}$, Yuliya Pisna ${ }^{5}$ \\ 1,2*3,4,5 Oles Honchar Dnipro National University, 35, Yavornitskogo str., Dnipro, 49000, Ukraine \\ E-mail: ${ }^{2 *}$ koaduep@gmail.com
}

Received 18 January 2019; accepted 27 June 2019; published 30 September 2019

\begin{abstract}
The article determines the factors of effectiveness of the formation of the organizational culture of the enterprise and its role in ensuring personnel security. It was proven that an enterprise can improve the quality of personnel security by developing an organizational culture in order to obtain positive dynamics of changes in economic efficiency indicators. An econometric model was proposed for determining the level of dependence of economic parameters of an enterprise on the directions of development and transformation of organizational culture. A tool for assessing the state of the organizational culture of the enterprise and assessing its impact on personnel security was proposed.
\end{abstract}

Keywords: personnel security, organizational culture, culture carrier, management decisions, external environment, assessment of efficiency, econometric model.

Reference to this paper should be made as follows: Osetrova, O.; Prykhodko, O.; Glazunov, S.; Borysova, Y.; Pisna, Y. 2019. Organizational culture as a component of personnel security of the enterprise, Journal of Security and Sustainability Issues 9(1): 107-121.

http://doi.org/10.9770/jssi.2019.9.1(9)

JEL Classifications: C10; M14

\section{Introduction}

Constant changes in the external environment, complications in the industrial and commercial activities of enterprises, increasing the value of the time factor, expanding the enterprise's space and increasing the volume and speed of obtaining information and new knowledge create significant pressure on the overall organizational and economic security of the enterprise and increase the importance of internal sources of economic growth able to ensure production growth and protection of personnel, as the basis of economic potential. This very important resource capable of creating a flexible, adaptive and thus efficient production system becomes precisely the organizational culture, which, with qualitative parameters, is able to form the outlines of the personnel security of the enterprise.

\section{Literature Survey}

The study of the problems of the organizational culture of the enterprise and its personnel security, in recent years has been covered in the following scientific works of (Amah, 2006; Clarkson, et. al. 2011; Daft, 2003; Gibson, 1998; Jankalová, \& Jankal, 2017; Lok, Crawford, 1999; Reisyan, 2016; Robbins, and Judge, 2011; Zak, 2018; Lorincová et al., 2019; Kumar et al., 2019; Havierniková, Kordoš, 2019).

At the same time, it should be noted that the problem of effective development of the organizational culture of the enterprise and the degree of its influence on the effectiveness of personnel security, production activity is 
not sufficiently studied and requires constant updating and specification of methodological approaches (Drobyazko S., 2018, 2019). This determines the scientific value of this study.

The purpose of this scientific work is the theoretical and practical need to determine the organizational characteristics of the formation and development of organizational culture within the industrial enterprise, which is aimed at increasing the productivity of personnel.

\section{Methods}

We can argue that the formation of an organizational culture of an enterprise, as a system of interconnected elements, is inextricably linked with the fact that the internal environment interacts with the external environment and in the process of interaction, internal actors are integrated and adapted to the external environment. The formation of organizational culture occurs through the solution of two major tasks: internal integration and external adaptation (Bersin, et. Al. 2018). Internal integration is associated with finding ways to work together and coexist within the enterprise (Tab. 1).

Table 1. Strategies for the formation of a new type of organizational culture

\begin{tabular}{|c|l|}
\hline Type of strategy & \multicolumn{1}{c|}{ Content of strategy } \\
\hline 1. Cultural strategy & Formation of content of values, ethics, integrity and unity \\
\hline 2. Network strategy & Formation of living, developing network of associations \\
\hline 3. Leadership strategy & Leadership as a link in all organizational structures \\
\hline 4. Strategy of innovative thinking & Formation of teams that manage themselves with innovative thinking \\
\hline 5. Strategy of innovative processes & Introduction of simplified, open procedures that facilitate joint activities \\
\hline $\begin{array}{r}\text { 6. Strategy oriented on the external } \\
\text { environment }\end{array}$ & $\begin{array}{l}\text { Creation of an organization, an external environment that is self-corrected and adapts to the } \\
\text { culture }\end{array}$ \\
\hline 7. Strategy of change & Change in the way of change, strategic integration \\
\hline
\end{tabular}

Source: Stoner, et. al. 2001; Treven, et. al. 2008

The process of an organizational culture formation begins with the fact that internal subjects, as a system of social elements (Fig. 1), form a certain type of organizational culture as a result of interaction with the external environment.

\begin{tabular}{|c|c|c|c|}
\hline \multirow{5}{*}{ 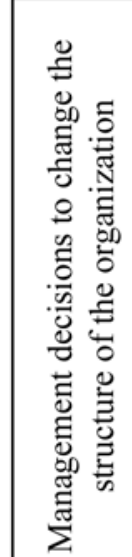 } & \multirow{5}{*}{ 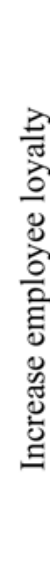 } & & Approaching personal goals with organizational goals \\
\hline & & & Reforming the organizational structure \\
\hline & & & Staff renewal and attraction of high-class specialists \\
\hline & & & $\begin{array}{l}\text { Increasing the level of competence of employees of the organization due } \\
\text { to the rotation and training of personnel of all levels and specialties }\end{array}$ \\
\hline & & & Reforming the system of payment and labor motivation \\
\hline
\end{tabular}

Fig. 1. Main directions of management initiatives for the formation of organizational culture 
An external adaptation is associated with search and finding by the enterprise of its niche in the market and its adaptation to the external environment, which is constantly changing. It should also be noted that the solution of two major tasks, and thus the formation of an organizational culture, is directly related to the life cycle of the enterprise. (Klassen, \& McLaughlin, 1996).

\section{Results}

Let's determine the main features of the target orientation of the enterprise at different stages of its development (tab. 2). Here, for analysis, we will use the competing values framework proposed by (DeRosa, 2017) and adapt it to domestic conditions.

Table2. Ratio of life cycle stages and features of its organizational culture

\begin{tabular}{|c|c|c|}
\hline Stage and purpose & $\begin{array}{c}\text { Type of strategy. Brief } \\
\text { description }\end{array}$ & Brief description of organizational culture features \\
\hline $\begin{array}{l}\text { Formation. } \\
\text { «Application» in the } \\
\text { market of goods / } \\
\text { services }\end{array}$ & $\begin{array}{l}\text { Entrepreneurial. } \\
\text { Attract attention to } \\
\text { the product, find own } \\
\text { consumer, organize sales } \\
\text { and service, become } \\
\text { attractive to the consumer }\end{array}$ & $\begin{array}{l}\text { Democratic type of organizational culture. } \\
\text { A cultural space is being formed within which: projects with } \\
\text { a high degree of financial risk are accepted; employees feel themsrlves as } \\
\text { innovators, they are initiative, willing to take risks, not afraid } \\
\text { of responsibility; management methods, labor, production stipulate } \\
\text { the required state of the environment, provide low staff turnover. }\end{array}$ \\
\hline $\begin{array}{l}\text { Intensive growth. } \\
\text { "System } \\
\text { multiplication" }\end{array}$ & $\begin{array}{l}\text { Dynamic growth. } \\
\text { An increasing growth in } \\
\text { production and quality, } \\
\text { and thus in the number of } \\
\text { structures }\end{array}$ & $\begin{array}{l}\text { Clan type of organizational culture. } \\
\text { A cultural space is being formed within which: there is a constant comparison } \\
\text { of current goals and the creation of a foundation for the future; written fixation } \\
\text { of policy of the enterprise and basic procedures; there is a close interaction of } \\
\text { employees, a high degree of internal integration; structural subdivisions, a high } \\
\text { degree of employee focus, and thus the flexibility of the enterprise in conditions } \\
\text { and other changing. }\end{array}$ \\
\hline $\begin{array}{l}\text { Stabilization } \\
\text { Consolidation in the } \\
\text { market, achieving the } \\
\text { maximum level of } \\
\text { profitability }\end{array}$ & $\begin{array}{l}\text { Profitability. } \\
\text { System support in } \\
\text { equilibrium }\end{array}$ & $\begin{array}{l}\text { Hierarchical type of organizational culture. } \\
\text { A cultural space is being formed within which: the existing level of profitability } \\
\text { is maintained; costs are minimized, termination of employment is possible; there } \\
\text { is a well-developed management system; employees achieve maximum results } \\
\text { (quantity and quality) at minimum cost and risk level, etc. }\end{array}$ \\
\hline \multirow[t]{2}{*}{$\begin{array}{l}\text { Recession. } \\
\text { Termination of } \\
\text { unprofitable costly } \\
\text { production } \\
\text { Recovery }\end{array}$} & $\begin{array}{l}\text { Liquidation. } \\
\text { Liquidation of a part } \\
\text { of the production, sale } \\
\text { with maximum benefit, } \\
\text { both financial and } \\
\quad \text { psychological }\end{array}$ & $\begin{array}{l}\text { Transition period to market organizational culture. A cultural A cultural space } \\
\text { is being formed within which: there is a sale of assets, elimination of losses and } \\
\text { reduction of employees, employees are loyal to the enterprise }\end{array}$ \\
\hline & $\begin{array}{l}\text { Entrepreneurial / } \\
\text { Liquidation }\end{array}$ & $\begin{array}{l}\text { Market organizational culture. } \\
\text { A cultural space is being formed within which: there is a purpose to save the } \\
\text { enterprise; actions are being taken to cut costs over the long term; the style of the } \\
\text { enterprise is a line that is rigidly carried out on competitiveness, and accordingly } \\
\text { - an orientation to the external environment and not to internal affairs; orientation } \\
\text { to long-term goals, dedication, willingness to feel temporary discomfort in the } \\
\text { conditions and wages, etc. }\end{array}$ \\
\hline
\end{tabular}

Source: Designed by the authors

1) Formation stage. In the conditions of market relations, goals are defined through the clarification of ideas about the consumer, his specific needs and their correlation with ideas about the objectives of the enterprise.

2) Stage of consolidation in the market. A cultural space is being formed, within which there is a constant comparison of current goals and the creation of a foundation for the future, a focus on finding and producing goods and services, expanding the range of consumers, suppliers and partners, there is a close interaction of workers and a high degree of purposefulness in achieving their goals, there is dedication to business and dedication to the enterprise and a unique image of the company is established. (Cui, \& $\mathrm{Hu}, 2012$ ). 
Thus, developing over time, enterprises supplement the adhocratic culture with a clan culture - a sense of family, a strong sense of unity with the team and personal involvement in the enterprise.

3) The stabilization stage is associated with consolidating what has been achieved, which in turn will require from the enterprise no less, if not more, effort than the goals of the previous stages. This is due to the fact that the problems that need to be addressed at this stage are predominantly internal in nature and are associated primarily with the consolidation of the organizational culture of the enterprise (Makedon 2019). The key values are concentrated around supporting profitability, reliability, speed of service, smoothness of the production process. Thus, standardized rules and procedures, control and accounting mechanisms are important at this stage (Ristic, et. al. 2017).

4) The crisis stage of the enterprise is the most difficult stage of its existence, since this resistance to the crisis and the search for ways out of the critical state is associated with a change in paradigms, values, targets, and thus a change in the existing organizational culture. Hierarchical orientation is gradually complemented by a focus on market culture - competitiveness, the desire to achieve results, and a focus on external relationships (Sulphey, \& Alkahtani, 2017).

Thus, at each stage, the enterprise implements a specific development strategy. Looking at the enterprise through the prism of stages allows you to more accurately identify its main target and strategic tasks and orientations (Brown, et. al. 2015). Moreover, it is possible to determine the extent to which they are consistent with the organizational culture of the enterprise, the distinctive characteristics of which are characteristic for each stage (Table 3).

Table 3. Assessment of personnel security and organizational culture of the enterprise

\begin{tabular}{|c|c|c|c|}
\hline \multicolumn{2}{|r|}{ 1. The most important characteristics of personnel security } & Now & Forecast \\
\hline A & The organization is unique in its features. It is like a big family. & & \\
\hline B & $\begin{array}{l}\text { People seem to have a lot in common. The organization is very dynamic and filled with } \\
\text { entrepreneurship. People are willing to sacrifice themselves and take risks. }\end{array}$ & & \\
\hline $\mathrm{C}$ & $\begin{array}{l}\text { The organization is result oriented. The main concern is to get the job done. People are focused on } \\
\text { rivalry and achievement of the goal. }\end{array}$ & & \\
\hline $\mathrm{D}$ & $\begin{array}{l}\text { The organization is strictly structured and strictly controlled. People's actions are usually determined by } \\
\text { formal procedures. }\end{array}$ & & \\
\hline & Total: & 100 & 100 \\
\hline \multicolumn{2}{|r|}{ 2. General leadership style in the organization } & Now & Forecast \\
\hline A & A general leadership style in the organization is an example of monitoring, aspiration to help or teach. & & \\
\hline B & $\begin{array}{l}\text { A general leadership style in the organization serves as an example of entrepreneurship, innovation, and } \\
\text { risk appetite. }\end{array}$ & & \\
\hline $\mathrm{C}$ & $\begin{array}{l}\text { The general style of leadership in the organization serves as an example of business efficiency, } \\
\text { aggressiveness, focus on results. }\end{array}$ & & \\
\hline $\mathrm{D}$ & $\begin{array}{l}\text { The overall style of leadership in the organization is an example of coordination, clear organization or } \\
\text { smooth conduct of business in line with profitability. }\end{array}$ & & \\
\hline & Total: & 100 & 100 \\
\hline \multicolumn{2}{|r|}{ 3. Employee Management } & Now & Forecast \\
\hline A & $\begin{array}{l}\text { The management style in the organization is characterized by encouraging teamwork, unanimity and } \\
\text { participation in decision making.. }\end{array}$ & & \\
\hline B & $\begin{array}{l}\text { The management style in the organization is characterized by encouraging individual risk, innovation, } \\
\text { freedom and identity. }\end{array}$ & & \\
\hline $\mathrm{C}$ & $\begin{array}{l}\text { The management style of the organization is characterized by high demands, a strong desire for } \\
\text { competitiveness and encouraging for achievements. }\end{array}$ & & \\
\hline $\mathrm{D}$ & $\begin{array}{l}\text { The management style of the organization is characterized by job security, requirement of } \\
\text { subordination, predictability and stability in relationships. }\end{array}$ & & \\
\hline
\end{tabular}




\begin{tabular}{|c|c|c|c|}
\hline & Total: & 100 & 100 \\
\hline \multicolumn{2}{|r|}{ 4. Binding essence of the organization } & Now & Forecast \\
\hline A & $\begin{array}{l}\text { The organization is bound together by dedication and mutual trust. The commitment of the organization } \\
\text { is high. }\end{array}$ & & \\
\hline $\mathrm{B}$ & $\begin{array}{l}\text { The organization is bound together by a commitment to innovation and improvement. It emphasizes the } \\
\text { need to be at the forefront. }\end{array}$ & & \\
\hline $\mathrm{C}$ & $\begin{array}{l}\text { The organization is bound together by an emphasis on achieving the goal and performing the task. } \\
\text { Common issues are aggressiveness and victory. }\end{array}$ & & \\
\hline \multirow[t]{2}{*}{$\mathrm{D}$} & $\begin{array}{l}\text { The organization is bound together by formal rules and official policy. Support id important for the } \\
\text { smooth running of the organization. }\end{array}$ & & \\
\hline & Total: & 100 & 100 \\
\hline \multicolumn{2}{|r|}{ 5. Strategic goals } & Now & Forecast \\
\hline A & $\begin{array}{l}\text { The organization focuses on humane development. High trust, openness and complicity are persistently } \\
\text { maintained. }\end{array}$ & & \\
\hline $\mathrm{B}$ & $\begin{array}{l}\text { The organization focuses on acquiring new resources and solving new problems. Approbation of new } \\
\text { and research opportunities are appreciated. }\end{array}$ & & \\
\hline $\mathrm{C}$ & $\begin{array}{l}\text { The organization focuses on competitive actions and achievements. The target strength of forces and the } \\
\text { desire to win in the market are dominated. }\end{array}$ & & \\
\hline \multirow[t]{2}{*}{$\mathrm{D}$} & $\begin{array}{l}\text { The organization focuses on immutability and stability. The most important things are profitability, } \\
\text { control and smoothness of all operations }\end{array}$ & & \\
\hline & Total: & 100 & 100 \\
\hline \multicolumn{2}{|r|}{ 6. Criteria for success } & Now & Forecast \\
\hline A & $\begin{array}{l}\text { The organization determines success based on the development of human resources, teamwork, } \\
\text { employee's enthusiasm for work and care for people. }\end{array}$ & & \\
\hline B & $\begin{array}{l}\text { The organization determines success based on ownership of a unique or state-of-the-art product. It is a } \\
\text { production leader and innovator. }\end{array}$ & & \\
\hline $\mathrm{C}$ & $\begin{array}{l}\text { The organization determines success on the basis of winning the market and competitors. Key to } \\
\text { success - competitive market leadership }\end{array}$ & & \\
\hline \multirow[t]{2}{*}{$\mathrm{D}$} & $\begin{array}{l}\text { The organization determines success on the basis of profitability. Success is determined by reliable } \\
\text { supply, smooth schedules and low operating costs. }\end{array}$ & & \\
\hline & Total: & 100 & 100 \\
\hline
\end{tabular}

Source: Designed by the authors

Having passed this preparatory stage, you can proceed to the change process - the change program and assess how successfully you were able to carry out this process. The main stages of its implementation: Assessment changes - assessment (Korsakienè, 2018).

In the assessment tool presented in the Table 3, the answer column has a "Now" header (this means that you rate your organization as it is at present) and "Mostly" (this means that you are rating, which, in your opinion, the same organization should be in order to get to the top of success).

As a result of the interaction of internal subjects of individuals within the system and with the external environment, a common culture is made for this group: a system of basic values, goals, ideas, norms, rules, which implies the development of a strategy (Allen, \& Shanock, 2013; Bradley, \& Parker 2001) and setting key goals for the most important functional areas and subsystems. As a result, a certain management culture, a labor culture, a production culture, a culture of relations and communications, and, accordingly, an organizational culture of an enterprise, are formed, since all these aspects of the organization of production activities are its structural elements and determine the realization of the goals (Strielkowski et al. 2016; Tvaronavičienè, 2018).

Accordingly, the relationship and the organization level of its structural elements determine the level of the organizational culture of the enterprise, which leads to the formation of a certain cultural space (Korauš, et. al. 2017), within which the enterprise's production activities aimed at achieving the goals are carried out on the basis of the system of established values. 
Taking into account the studied concepts and approaches, the authors propose their own approach to the study of organizational culture and its impact on the personnel security of the enterprise. The case is based on the organizational and personnel indicators of the machine-building enterprise PJSC (private joint stock company) "AutoKrAZ". Our task was to determine the methodology for quantifying the organizational culture of the enterprise, assess its impact on personnel security, test it in practice and establish a close relationship between the organizational culture of the enterprise and performance indicators based on the results of the study.

To quantify the organizational culture of the enterprise, we developed a questionnaire, the final version of which includes 111 statements, each of which assesses (measures) the state of one of the 18 elements of the organizational culture of the enterprise. This number is quite close to the optimal, because it allows you to provide the necessary depth and coverage of the study, but at the same time does not overload the respondents with a large amount of information, which is important for the reliability of the study. In addition, 3-9 questions were compiled to assess each of the 18 elements (Malhotra, \& Murnighan, 2002).

Here we paid special attention to ensuring that each question was assessed by only one of the 18 elements and was minimally related to the others. This is important because the value of each element in quantitative units, obtained as a result of a survey, should show the severity of this particular element, and no other.

Answering each question, the employee was asked to indicate a measure of agreement with each statement on a seven-point scale (the scale of response options can vary from 3 to 7), which is proposed for use by Likert and received the name of a Likert type questionnaire. In our case, the scale had the following gradation: completely disagree (1 point), mostly disagree (2), partially disagree (3), not decided (4), partially agree (5), mostly agree (6), completely agree (7). According to experts, the reliability of the questionnaire increases with the number of response options, but begins to decrease when the number of response options reaches 1 (Balkar, 2015). Thus, a seven-point scale improves the reliability of the study, but does not create difficulties when choosing the right option for answer for respondents.

It should also be noted that the questionnaire included both positive and negative formulations. For example, a question aimed at studying the culture of work organization could sound like this: "The level of labor discipline in your enterprise is quite high," or so: "In your enterprise, violations of labor discipline often occur." The alternation of positive and negative statements allows us to trace the truthfulness and attentiveness of the respondents, that is, it increases the reliability of the questionnaire (Prakapavičiūtè, Korsakienè, (2016).

Thus, the resulting assessment tool - the questionnaire presented in Appendix I can be described as follows:

- 111 negative and positive questions;

- multiple response format (seven-point scale);

Questions are grouped thematically into 18 sections, however, they are regrouped randomly in the questionnaire itself.

We calculated the votes for each of the questions as follows: for positively formulated answers, the number of points answered the respondent's answer, for negatively formulated questions, the number of points was calculated using the formula:

$$
(x+1)-y
$$

where, $x$ - number of possible answer options (in our case - 7),

$\mathrm{y}$-number of points corresponding to the answer of the respondent, respectively, the formula has the following form:

$$
(7+1)-y
$$

Then, the number of points for each of the 18 elements of the organizational culture at PJSC "AutoKrAZ" was calculated. We summarized these values of cultural elements in the enterprise and received the total number of culture points. 
We calculated the average value of the organizational culture per employee, dividing the total score of the organizational culture of this enterprise by the number of respondents who filled out the questionnaires. Note, the maximum value of the organizational culture of the enterprise in our study is 777 points (111x 7 points), that is, a strong organizational culture should correspond to the 777 mark. Accordingly, the higher the score of organizational culture in the studied enterprises is, the higher its level and strength. At the same time, according to the results of the survey, we evaluated the degree of homogeneity of 18 structural elements of culture at each enterprise under study.

The average value of the level of organizational culture of the enterprise:

$$
\bar{C}=\frac{E 1+E 2+E 3+\ldots .+E 18}{n}
$$

where, E1, E2, E3...E18 - elements of the organizational culture of the enterprise; $n$ - number of respondents.

In order to determine the degree of reliability of the questionnaire compiled by us, and thereby substantiate the legitimacy of its further use to assess the state of the organizational culture of enterprises for its quantitative measurement, we calculated the Cronbach's $\alpha$ coefficient (Yousef, 2017). The Cronbach's $\alpha$ coefficient - is a statistical indicator that measures the degree of internal homogeneity of the questionnaire, or the internal consistency of all questions. That is, the verification of the reliability of the assessment of 18 elements of an organizational culture using the Cronbach's $\alpha$ coefficient (reliability index) shows to which extent the questions, combined into each group, are reliable, internally homogeneous and measure one and the same element (true mark). This step is very important, because in the absence of proper verification of the reliability of questionnaire, all further work may be based on a false basis. The Cronbach's $\alpha$ was calculated in MS Excel for each group of questionnaire questions, evaluating one of the elements of the organizational culture of the PJSC "AutoKrAZ" using the following formula:

$$
\alpha=\left(\frac{k}{k-1}\right) \times\left(1-\frac{\sum \sigma_{i}^{2}}{\sigma_{c y M}^{2}}\right)
$$

where, $k$-number of questions in the group responsible for assessing the element of organizational culture

$\sigma^{2 i}$ - variance for each individual question in this group

$\sigma_{c y M}^{2}-$ variance for the sum of the values for all questions in this group.

The calculated values of the Cronbach's $\alpha$ coefficient are shown in table 4.

Since all the values of the Cronbach's $\alpha$ coefficient for each group of questions are greater than 0.7 , the reliability of the questionnaire developed by us is high and each question measures exactly the element of culture that it should measure. Here we used the next rule.

If the Cronbach's $\alpha$ coefficient for a group of questions that determine the level of organization of each element:

- is equal to 1.00 , then all the questions that assess this element are absolutely reliable and measure it;

- is more than 0.70 , then the reliability of this group of questions is sufficient;

- is equal to 0.60 , then the level of reliability is as minimal as possible, and accordingly, it is necessary to finalize the question before the test set can be used for large-scale research (Van Vianen, et. Al. 2011). 
Table 4. The values of the Cronbach's $\alpha$ coefficient

\begin{tabular}{|c|l|c|}
\hline № & \multicolumn{1}{|c|}{ Element of organizational culture } & Cronbach’s $\alpha$ \\
\hline 1 & Clarity of goals and focus on their achievement & 0,807 \\
\hline 2 & Focused production activity (strategic orientation) & 1,000 \\
\hline 3 & Management style & 0,839 \\
\hline 4 & Level of formality & 0,775 \\
\hline 5 & Ability to resolve conflicts & 0,803 \\
\hline 6 & Personnel orientation & 0,704 \\
\hline 7 & Internal integration & 0,778 \\
\hline 8 & Participation of employees in the decision-making process & 0,785 \\
\hline 9 & Delegation of authority & 0,792 \\
\hline 10 & Commitment to common goals & 0,784 \\
\hline 11 & Employee remuneration system & 0,882 \\
\hline 12 & Management of the system of values & 0,771 \\
\hline 13 & Customer and high quality orientation & 0,902 \\
\hline 14 & Orientation to changes & 0,781 \\
\hline 15 & Learning orientation & 0,717 \\
\hline 16 & Labor conditions, discipline and labor protection & 0,895 \\
\hline 17 & Level of production organization & 0,926 \\
\hline 18 & Technical level of production & 0,895 \\
\hline
\end{tabular}

Source: calculation authors

Thus, on the basis of the calculations, we statistically proved the reliability of the questionnaire and the possibility of its further use for conducting similar studies.

Next, after conducting a correlation-regression analysis, we:

- determined the relationship of 18 structural elements of the organizational culture among themselves, by calculating the matrix of paired correlation coefficients and determining the coefficients of determination $\left(R^{2}\right)$;

- built the equation of paired linear regressions, allowing to establish in which direction and by what amount the effective element changes when the factor element changes by 1 point;

- statistically selected elements that determine the organizational culture of the enterprise by identifying a close correlation relationship between the organizational culture and these elements; built the equation of multiple linear regression of the dependence of culture on the selected elements, which determine it to a greater degree. In particular, first in MS Excel we built a matrix of paired correlation coefficients between the 18 elements of the organizational culture, which we considered as factor indicators for the effective feature - the organizational culture of the enterprise.

In order to assess the absolute influence (in points) of one cultural element on another, we assessed paired linear regressions. Mathematically, the task was reduced to finding an analytical expression, and it is the best way to describe the connection of one cultural element with another in the form:

where $y$-effective feature

$$
y=a+b x
$$

$x$ - factor feature.

The coefficient $b$ shows in how many points the effective feature changes with an increase in the factor feature by 1 point.

For example, for element 1 "clarity of goals and focus on their achievement", factor features are element 2 "focused production activity", element 8 "employee participation in decision making" and element 13 "manage- 
ment of the system of values". Looking at the value of b in Appendix 10, we can conclude that by increasing each of these elements by 1 point, element 1 "clarity of goals and focus on their achievement " will increase by $1.20 ; 1,0.47$, respectively.

The matrix of paired correlation coefficients also allowed us to answer the question, which elements largely determine the organizational culture of the enterprise. According to the calculations, there are 12 of them and they are all listed in Table 5, where the values of the correlation coefficients, the determination coefficients and the value of $b$ from the regression equations are presented. The value of $b$ in this case shows that with the increase, for example, of element 14 "orientation to changes" by 1 point, the value of the organizational culture of the enterprise will increase by 22.68 points.

Table 5. Factor features that determine personnel security and organizational culture of the PJSC "AutoKrAZ"

\begin{tabular}{|c|c|c|c|c|}
\hline Element No. & Factor feature & $\begin{array}{c}\text { Correlation } \\
\text { coefficient }(r)\end{array}$ & $\begin{array}{c}\text { Determination } \\
\text { coefficient }\left(R^{2}\right)\end{array}$ & Value of $b$ \\
\hline Element 14 & Orientation to changes & 0,90 & 0,81 & 22,68 \\
\hline Element 2 & Focused production activity & 0,88 & 0,77 & 2,16 \\
\hline Element 17 & Level of production organization & 0,87 & 0,74 & 9,05 \\
\hline Element 18 & Technical level of production & 0,86 & 0,74 & 11,76 \\
\hline Element 7 & Internal integration & 0,85 & 0,72 & 19,85 \\
\hline Element 1 & Clarity of goals and focus on their achievement & 0,83 & 0,69 & 15,88 \\
\hline Element 15 & Learning orientation & 0,83 & 0,68 & 23,17 \\
\hline Element 16 & Labor conditions, discipline and labor protection & 0,73 & 0,53 & 10,71 \\
\hline Element 3 & Management style & 0,70 & 0,50 & 10,21 \\
\hline Element 10 & Commitment to common goals & 0,70 & 0,50 & 23,24 \\
\hline Element 12 & Management of the system of values & 0,70 & 0,50 & 15,57 \\
\hline Element 13 & Customer orientation & 0,68 & 0,50 & 18,32 \\
\hline
\end{tabular}

Source: calculation authors

However, the results obtained do not mean that the remaining 6 elements do not determine the organizational culture of the enterprise. Accordingly, we believe that all the 18 elements that have been identified define the organizational culture and are its structural elements.

Further, in order to solve the problem of selecting factor features and the problem of multicollinearity, we conducted a static analysis using the method of step-by-step regression (Korlén, et. al. 2018). The concept of this method lies in the sequential inclusion of factors in the regression equation and the subsequent verification of their significance. As a result, the following equation was obtained:

$$
C=\alpha_{0}+\alpha_{1} E_{1}+\alpha_{14} E_{14}+\alpha_{18} E_{18}
$$

where, $\mathrm{C}$ - organizational culture of the enterprise

$\alpha_{0}$ - constant,

$\alpha_{1,} \alpha_{14} \alpha_{18}-$ coefficients of regression,

$E 1, E 14, E 18$ - elements defining organizational culture (factor features).

This equation of the dependence of culture on factor features has taken the following form:

$$
C=-15,04+5,12 E_{1}+4,56 E_{14}+5,93 E_{18}
$$


Thus, as a result of the correlation and regression analysis, we found that there is a high connection strength between the selected factor features and the organizational culture of PJSC "AutoKrAZ", since the multiple correlation coefficient $r$ is 0.98 . At the same time, $96.5 \%$ of changes in the organizational culture of an enterprise are due to changes in element 1, "clarity of goals and focus on their achievement," element 14, "enterprise's ability to respond to changes," and element 18, "technical level of production". In particular, the regression coefficients show that with an increase in element 1 "clarity of goals and orientation on their achievement" by 1 point, the organizational culture of the enterprise will increase by 5.12 points, with an increase in element 14 , "orientation to changes" by 1 point, the organizational culture of the enterprise will increase by 4.56 points, with an increase in element 18 «technical level of production» by 1 point, the organizational culture of the enterprise will increase by 5.93 points (Herzberg, 2017).

When checking the significance of the equation based on Fisher's F-criterion, in particular, when comparing the calculated value $F=82.9$ and the critical value FKpum $=3.86$ at a significance level of 0.05 , we found that the equation is significant and the relationship is recognized as significant.

In order to assess the statistical significance: the impact of enterprise organizational culture on personnel security of the enterprise and production activity, we also conducted a correlation-regression analysis. Three indicators of efficiency were taken as a basis: labor productivity and profitability of the main activity.

As a result of the analysis, we found a fairly close relationship between the organizational culture of the enterprise and labor productivity (Fig. 2). This is indicated by a correlation coefficient of $r=0.67$. At the same time, $45 \%$ of changes in labor productivity are due to changes in the organizational culture of the enterprise $\left(\mathrm{R}^{2}=0.45\right)$.

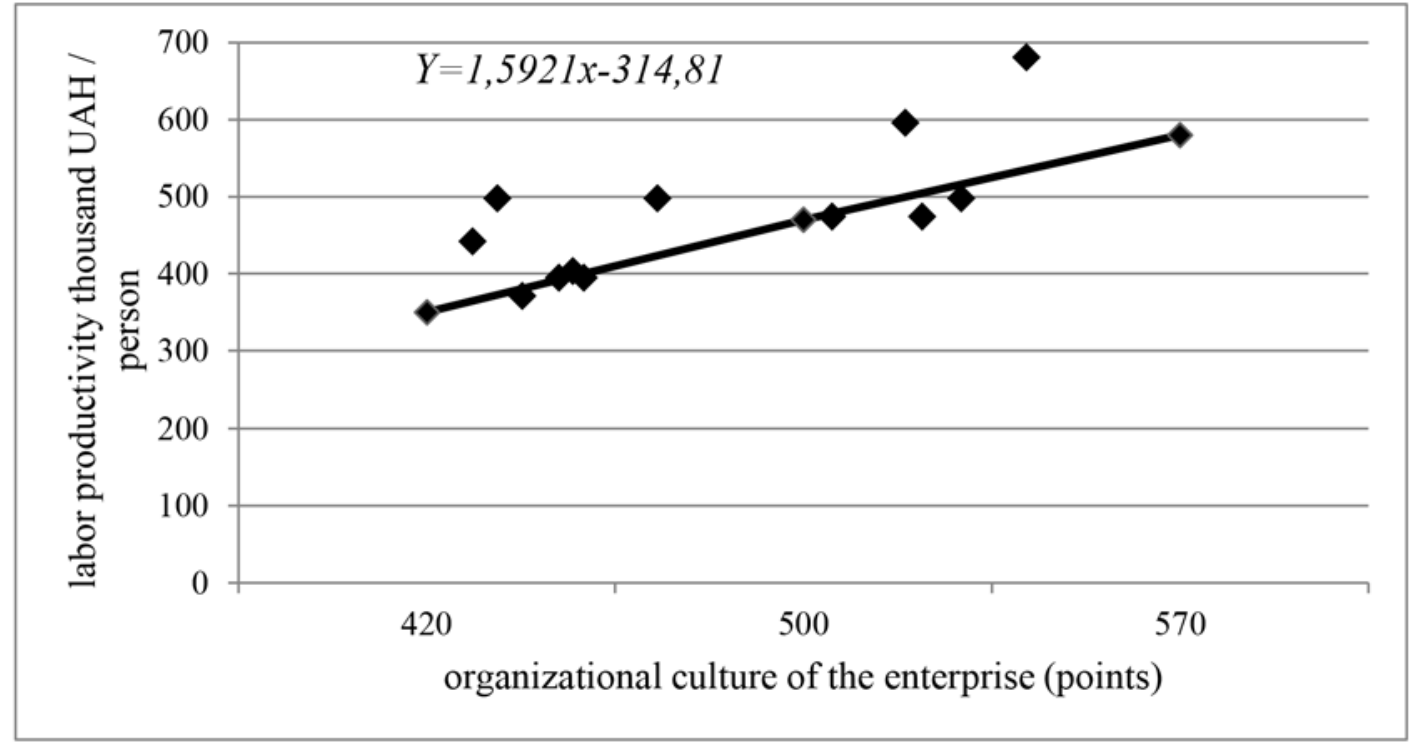

Fig. 2. Relationship between productivity and organizational culture of the PJSC «AutoKrAZ»

Source: Designed by the authors

We built the equation of paired linear regression of the form:

$$
\Pi=\alpha_{0}+b x C
$$

where $\Pi$ - labor productivity (effective feature);

$\alpha_{0}-$ constant;

$b$ - coefficient of regression; 
$C$ - organizational culture of the enterprise (factor feature), and obtained the following equation for the dependence of labor productivity on the organizational culture of the enterprise:

$$
\Pi=-314,18+1,59 C
$$

The regression coefficient $b$ in this case shows us that with an increase in the value of the organizational culture of the enterprise by 1 point, the indicator of labor productivity increases by 1.60 thousand UAH / people.

\section{Discussion}

We also determined confidence intervals for labor productivity, as a factor in personnel shortage when the organizational culture of the enterprise changes by 1 point. Thus, if the organizational culture of the enterprise changes by 1 point with a probability of 0.95 , labor productivity may change to a value from the interval $(0,41$; 2,79).

As a result of the analysis, we found a close relationship between the organizational culture of the PJSC " $\mathrm{Au}$ toKrAZ" and the profitability of the main activity. This is evidenced by the correlation coefficient $r=0.70$. At the same time, $50 \%$ of the change in the profitability of the main activity of the enterprise is due to a change in its organizational culture $\left(\mathrm{R}^{2}=0.50\right)$.

We built the equation of paired linear regression of the form:

$$
R=\alpha_{0}+b x C
$$

where $R$-profitability of the main activity (effective feature);

$\alpha_{0}-$ constant;

$b$ - coefficient of regression.

$C$ - organizational culture of the enterprise (factor feature), and obtained the following equation for the dependence of labor productivity on the organizational culture of the enterprise:

$$
\Pi=-31,3+0,08 C
$$

Regression coefficient $b$ shows that with an increase in the organizational culture of the enterprise by 1 point, the profitability index of the main activity will increase by $0.08 \%$. We also set confidence intervals for the profitability of the main activity when the organizational culture of the enterprise changes by 1 point. (Weiner, (2018). Thus, if the organizational culture of an enterprise changes by 1 point with a probability of 0.95 , the profitability of the main activity may change to a value from the interval $(0.03 ; 0.14)$ (Fig. 3$)$. 


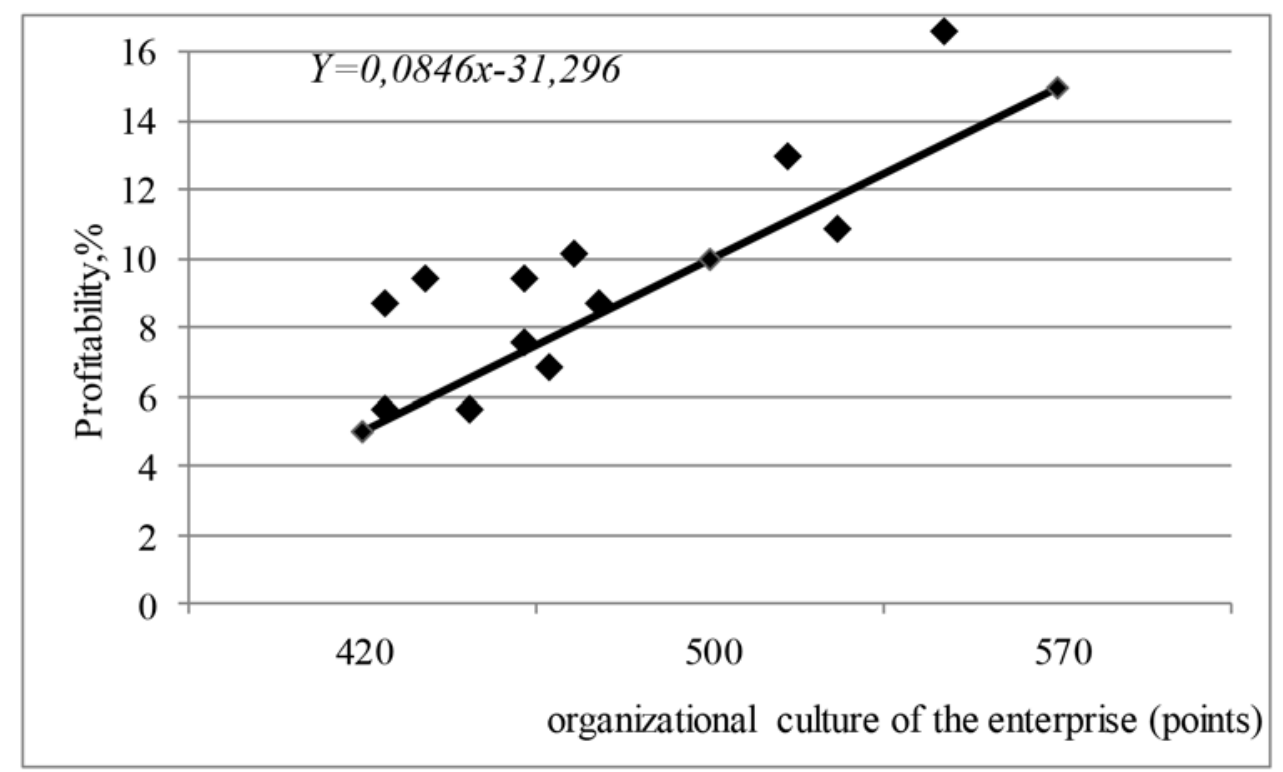

Fig. 3. Relationship between profitability of sales and organizational culture of the PJSC «AutoKrAZ»

Source: Designed by the authors

We also set confidence intervals for the profitability of sales when the organizational culture of the enterprise changes by 1 point. Thus, if the organizational culture of an enterprise changes by 1 point with a probability of 0.95 , the return on sales may change to a value from the interval. $(0,03 ; 0,13)$.

\section{Conclusions}

Thus, the formation of the organizational culture of the enterprise is associated with the formation of a system of elements that determine the functioning of the enterprise in all areas, ranging from the strategy for its development to the process of fulfilling its functional responsibilities by each individual in order to ensure proper personnel security. Having formed, the organizational culture of the enterprise determines the further personnel and production development of the enterprise. That is, how the enterprise adapts to the external environment, which is constantly changing, what goals it sets, what methods it uses to achieve its goals, is determined by the level of the established organizational culture of the enterprise, which affects the spiritual and physical development of individuals as part of the organization of production activities of the enterprise.

As part of the case study, the analysis shows that there is a close positive correlation between the organizational culture of the PJSC "AutoKrAZ" and the indicators of the efficiency of its production activities, that is, the higher the level of organizational culture of the enterprise is, the higher the indicators of the efficiency of its production activities. In this case, we believe that:

- the strong organizational culture is a competitive advantage that enhances the ability of the enterprise to identify personnel capabilities to shape personnel security activities;

- the strong organizational culture enhances the efficiency of industrial enterprises in conditions of intense competition, since it allows them to coordinate all actions taking into account the conditions of the external environment in which the enterprise operates. 


\section{References}

Allen, D.G., \& Shanock, L.R. (2013). Perceived organizational support and embeddedness as key mechanisms connecting socialization tactics to commitment and turnover among new employees. Journal of Organizational Behavior, 34(3), 350-369. https://doi. org/10.1002/job.1805

Amah, E (2006). Human Resource Management. Amethyst Publishers Port Harcourt. DOI: 10.9790/487X-16230716

Balkar, B. (2015). The relationships between organizational climate, innovative behavior and job performance of teachers.International Online Journal of Educational Sciences, 7(2). URL: http://mts.iojes.net//userfiles/Article/IOJES_1552.pdf

Bersin, J., McDowell, T., Rahnema, A., \& Van Durme, Y. (2018). The organization of the future: Arriving now. Retrieved from https:// www2.deloitte.com/insights/us/en/focus/human-capital-trends/2017/organization-of-the-future.html

Bradley, L. and R. Parker (2001). Organisational Culture in the Public Sector, Report for the Institute of Public Administration Australia (IPAA), Australia: IPAA National. URL: http://unpan1.un.org/intradoc/groups/public/documents/apcity/unpan006307.pdf

Brown, D., Melian, V., Solow, M., Chheng, S., \& Parker, K. (2015). Culture and engagement. Retrieved from https://www2.deloitte. com/insights/us/en/focus/human-capital-trends/2015/employee-engagement-culture-human-capital-trends-2015.html

Cameron, K.S., Quinn, R.E. (2011). Diagnosing and changing organizational culture: Based on the competing values framework. San Francisco: A Wiley Imprint. URL: https://pdfs.semanticscholar.org/9095/28bece85d540beb496170045c1bec74ab8b6.pdf

Clarkson, P.M., Overell, M.B., \& Chapple, L. (2011). Environmental reporting and its relation to corporate environmental performance. Abacus, 47(1), 27-60. https://doi.org/10.1111/j.1467-6281.2011.00330.x

Cui, X., \& Hu, J. (2012). A Literature Review on Organization Culture and Corporate Performance. International Journal Of Business Administration, 3(2), 30-31. https://doi.org/10.5430/ijba.v3n2p28

Daft, R.L. (2003). OrganizationTheory and Design, Southwestern College Publishing, Cincinnati, Ohio.

DeRosa, D. (2017). Preparing for Change: 2018 Organizational Development Trends. Retrieved from https://www.onpointconsultingllc. $\mathrm{com} / \mathrm{blog} /$ preparing-for-change-2018-organizational-development-trends

Drobyazko S. (2018). Features of the GE/McKinsey model application for assessing the positions as a factor of security of insurance enterprises. International scientific journal "Internauka". Series: "Economic Sciences". 10(18), 78 c. - P. 9-11. https://doi. org/10.25313/2520-2294-2018-10-4788

Drobyazko S. (2019). Results of introduction of the improved mechanism of economic security control of insurance companies // International scientific journal "Internauka". Series: “Economic Sciences”. — 2019. — №1 - - 78 c. - P. 9-11. https://doi.org/10.25313/25202294-2019-1-4783

Felin, T., \& Powell, T. (2016). Designing Organizations for Dynamic Capabilities. California Management Review, 58(4), 78-96. https://doi.org/10.1525/cmr.2016.58.4.78

Gibson, I.D. (1998). Organization: Behavior, structure, process, translation: Djarkasih, I, II. SalembaEmpat, Jakarta. URL: http:// dl.motamem.org/organizations_behavior_structure.pdf

Havierniková, K., Kordoš, M. (2019). Selected risks perceived by SMEs related to sustainable entrepreneurship in case of engagement into cluster cooperation. Entrepreneurship and Sustainability Issues, 6(4), 1680-1693. http://doi.org/10.9770/jesi.2019.6.4(9)

Herzberg, F. (2017). Motivation to work. Routledge.

Jankalová, M.; Jankal, R. (2017). The assessment of corporate social responsibility: approaches analysis, Entrepreneurship and Sustainability Issues 4(4): 441-459. https://doi.org/10.9770/jesi.2017.4.4(4)

Klassen, R.D., \& McLaughlin, C.P. (1996). The impact of environmental management on firm performance. Management Science, 42(8), 1199-1214. https://doi.org/10.1287/mnsc.42.8.1199

Korauš, A., Kaščáková, Z., Parová, V., Veselovská, S. (2017). Sustainable economic development through human resource management: social intelligence of managers and performance. Journal of Security and Sustainability Issues, 6(3): 457-477. http://dx.doi. org/10.9770/jssi.2017.6.3(11)

Korlén, S., Essén, A., Lindgren, P., \& Amer-Wåhlin, I. (2018). Leaders as intermediates between economic incentive models and professional motivation. Lakartidningen. 
Korsakienè, K. (2018). Towards sustainable defence organization: values congruence and organizational commitment, Journal of Security and Sustainability Issues 7(4): 697-705. https://doi.org/10.9770/jssi.2018.7.4(7)

Kumar, N.S., Haque, M.I., Venugopal, K. (2019). Employment challenges in Saudi Arabia: an attitudinal study. Entrepreneurship and Sustainability Issues, 6(4), 1637-1646. http://doi.org/10.9770/jesi.2019.6.4(6)

Lok, P., Crawford, J. (1999). The relationship between commitment and organizational culture, subculture, leadership style and job satisfaction in organizational change and development. Leadership and Organization Development Journal 20(7): 365-374. https://doi. org/10.1108/01437739910302524

Lorincová, S., Hitka, M., Bajzíková, L., Weberová, D. (2019). Are the motivational preferences of employees working in small enterprises in Slovakia changing in time. Entrepreneurship and Sustainability Issues, 6(4), 1618-1635. https://doi.org/10.9770/jesi.2019.6.4(5)

Malhotra, D., \& Murnighan, J.K. (2002). The effects of contracts on interpersonal trust. Administrative Science Quarterly, 47(3), 534559. https://doi.org/10.2307/3094850

Makedon, V., Hetman, O., Yemchuk, L., Paranytsia, N., Petrovska, S. (2019). Human resource management for secure and sustainable development, Journal of security and sustainability issues 8(3): 345-354. http://doi.org/10.9770/jssi.2019.8.3(5)

Prakapavičiūtè, J.; Korsakienė, R. (2016). The investigation of human capital and investments into human capital: Lithuania in the context of the EU, Entrepreneurship and Sustainability Issues 3(4), 350- 367. https://doi.org/10.9770/jesi.2016.3.4(4)

Reisyan, G. (2016). Neuroscience and Culture to Boost Innovation Power. Retrieved from https://www.humansynergistics.com/blog/ culture-university/details/culture-university/2016/12/20/neuroscience-and-culture-to-boost-innovation-power

Ristic, M.R., Selakovic, M., Qureshi, T.M. (2017). Employee motivation strategies and creation of supportive work environment in societies of post-socialist transformation. Polish Journal of Management Studies, 15(2), 205-216. https://doi.org/10.17512/pjms.2017.15.2.19

Robbins, S. and Judge, T. (2011). Organizational Behaviour. 14th Ed, Prentice Hall.

Strielkowski, W.; Lisin, E.; Tvaronavičienè, M. (2016). Towards energy security: sustainable development of electrical energy storage. Journal of Security and Sustainability Issues 6(2): 43-52. http://dx.doi.org/10.9770/jssi.2016.6.2(4)

Sulphey, M.M.; Alkahtani, N S. (2017). Economic security and sustainability through social entrepreneurship: the current Saudi scenario, Journal of Security and Sustainability Issues, 6(3), 479-490. http://dx.doi.org/10.9770/jssi.2017.6.3(12)

Stoner, J.F., Freeman, R.E. and Gilber, D.R. (2001). Management (Prentice - Hall of India).

Treven, S., Mulej, M., \& Lynn, M. L. (2008). The impact of culture on organizational behavior. Management: Journal of Contemporary Management Issues, 13(2), 27-39.

Tvaronavičienė, M. (2018). Towards internationally tuned approach towards critical infrastructure protection. Journal of Security and Sustainability Issues, 8(2), 143-150. https://doi.org/10.9770/jssi.2018.8.2(2)

Van Vianen A. E. M., Shen C.-T., Chuang A. (2011). Person-organization and person-supervisor fits: Employee commitments in a Chinese context. Journal of Organizational Behavior 32: 906-926. https://doi.org/10.1002/job.726

Weiner, Y. (2018). 99 Totally Serious Ways To Create A Great Work Culture. Retrieved from https://medium.com/thrive-global/99totally-serious-ways-to-create-a-great-work-culture-e7d093bdad23

Yousef, D.A. (2017). Organizational Commitment, Job Satisfaction and Attitudes toward Organizational Change: A Study in the Local Government. International Journal of Public Administration, 40(1): 77-88. https://doi.org/10.1080/01900692.2015.1072217

Zak, P. (2018). The neuroscience of high-trust organizations. Consulting Psychology Journal: Practice and Research, 70(1), 45-58. https://doi.org/10.1037/cpb0000076 
Oksana OSETROVA, Doctor of Philosophy, Professor, Oles Honchar Dnipro National University

ORCID ID: orcid.org/0000-0002-7598-1144

Olga PRYKHODKO, Candidate of Science with the state administration, Associate professor, Oles Honchar Dnipro National University

ORCID ID: orcid.org/0000-0002-4999-5964

Stanislav GLAZUNOV, Candidate of historical sciences, Associate Professor, Oles Honchar Dnipro National University ORCID ID: orcid.org/ 0000-0002-1011-4971

Yuliia BORYSOVA, Candidate of sociological sciences, Associate professor, Oles Honchar Dnipro National University RCID: ID: orcid.org/0000-0001-9623-612X

Yuliya PISNA, Candidate of Philosophical Sciences, Associate Professor, Oles Honchar Dnipro National University ORCID ID: https://orcid.org/0000-0002-3436-2419

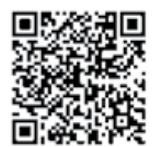

Register for an ORCID ID:

https://orcid.org/register

This work is licensed under the Creative Commons Attribution International License (CC BY). http://creativecommons.org/licenses/by/4.0/ 